\title{
Analysis of the displacement of road embankments and bridges located in areas prone to landslides
}

\author{
Elżbieta Pilecka*, and Karolina Tomaszkiewicz \\ Cracow University of Technology, Faculty of Civil Engineering, Cracow, Poland
}

\begin{abstract}
Landslides are a common problem in road engineering. Therefore, at the stage of designing new roads, it is preferable to design them in such a way as to avoid as many landslide areas as possible. In the case of existing roads running through landslide areas, one of the solutions designed to eliminate road embankment damage caused by landslide movement is to divert traffic over the landslide using a bridge structure. The article presents the results of monitoring road embankments located in a landslide prone location and a bridge, which serves to divert the voivodeship road over the active landslide. The measurements were carried out using a terrestrial laser scanner. The differential model obtained during data analysis allowed for the determination of the area and size of deformation in the analyzed area.
\end{abstract}

Keywords: landslide, terrestrial laser scanning, displacement monitoring, differential model

\section{Introduction}

The number of bridges which have been designed and built in landslide prone areas is relatively small. The newly designed routes have been conducted in such a way so as to avoid as many landslide prone areas as possible. However, the existing roads in landslide prone areas are a common problem. The effects of the activation of landslides often lead to significant restrictions on traffic or even to the closure of road sections.

One of the ways to solve the problems caused by the activation of landslides in the area followed by the road is to change its course in such a way so as to avoid dangerous areas. This solution, however, is very difficult, because it may cause a significant extension of the route, and thus it involves the need to purchase additional areas, it may even necessitate the demolition of existing buildings.

If it is not possible to change the course of the route, an alternative solution may be the construction of a bridge structure, which will be designed to carry traffic over the landslide and allow for the free movement of soil masses between abutments. It is important to monitor

\footnotetext{
*Corresponding author: epilecka@pk.edu.pl
} 
roads constructed on landslide prone areas, especially those for which protection has been applied [1-3].

One of the methods that is used to assess landslide activity is terrestrial laser scanning [4]. The study presents the results of measurements with a terrestrial laser scanner and an analysis of the displacements of the road embankment and the bridge which conducts the movement of vehicles and pedestrians over the area of active landslides.

\section{Landslide characteristics}

The landslide is located in the Lesser Poland Voivodeship, in Kąclowa, along Voivodeship Road No. 981, section 100 on the Grybów - Krynica Zdrój route (Fig. 1).

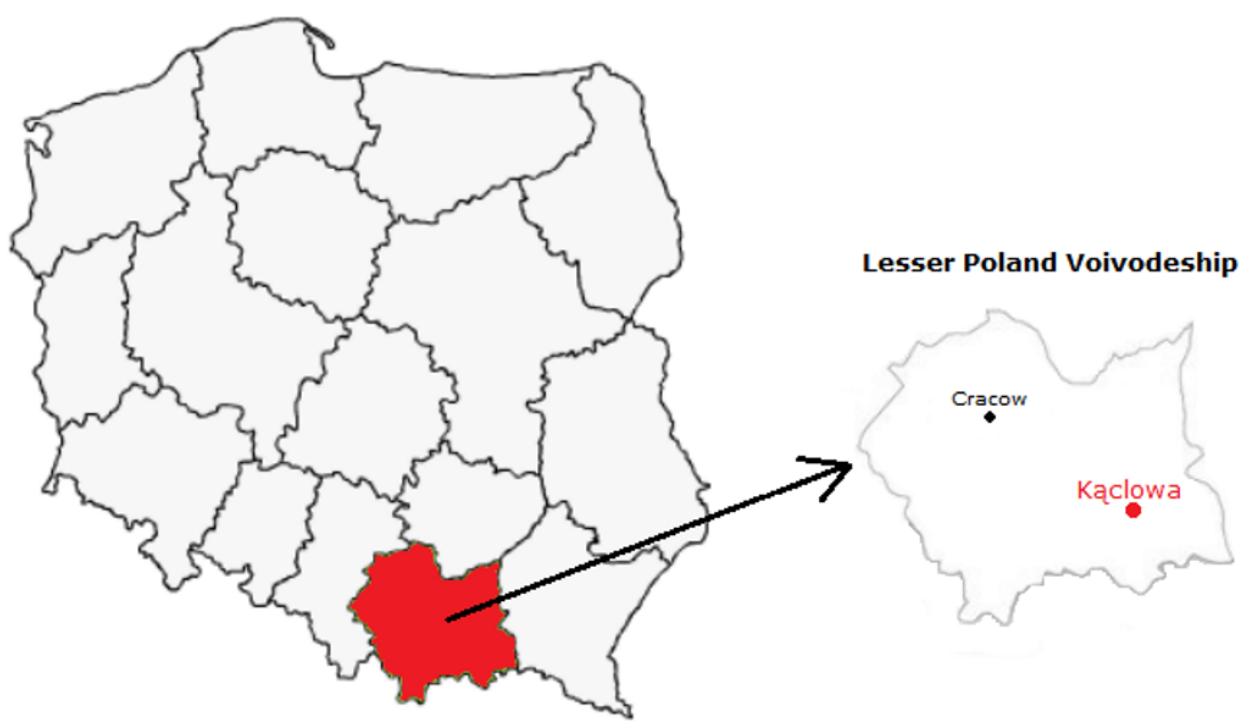

Fig.1. Location of the study area on the map of Poland.

The landslide became active in 2007 and 2010. At that time, along the eastern side of the road, protection in the form of micropiles topped with a cap was applied [5,6]. This protection slowed down gravitational movements and protected the road from breaking completely. In 2014 , as a result of rainfall, the landslide reactivated once again. A road fault with a height of $6-8 \mathrm{~cm}$ was created on the road at the border of the active landslide (Fig. 2). Due to the danger of using the damaged section of the road, a temporary road was constructed using concrete slabs on the west side and a temporary barrier was installed to prevent access to the damaged section of the road. Within the active landslide and near the landslide, there were many fresh intra-landslide slopes, thresholds, crevices, cracks, water exudation, and uneven terrain.

Monitoring with the ground laser scanner, which was conducted before the reconstruction of the road, showed that the displacements in this area were up to $(-50 \mathrm{~cm})$ from the starting location of the route [7]. The analysis also showed the impact of road vibration on the stability of the road embankments [8]. Given the circumstances, a good solution was to build a bridge over the landslide prone area.

Pursuant to the Regulation of the Minister of Transport, Construction and Maritime Economy of 25 April 2012 on the establishment of the geotechnical conditions of the foundation of buildings (Journal of Laws, item 463) [9] the soil conditions in the analyzed 
area were defined as complicated, and the bridge was included in the third geotechnical category.

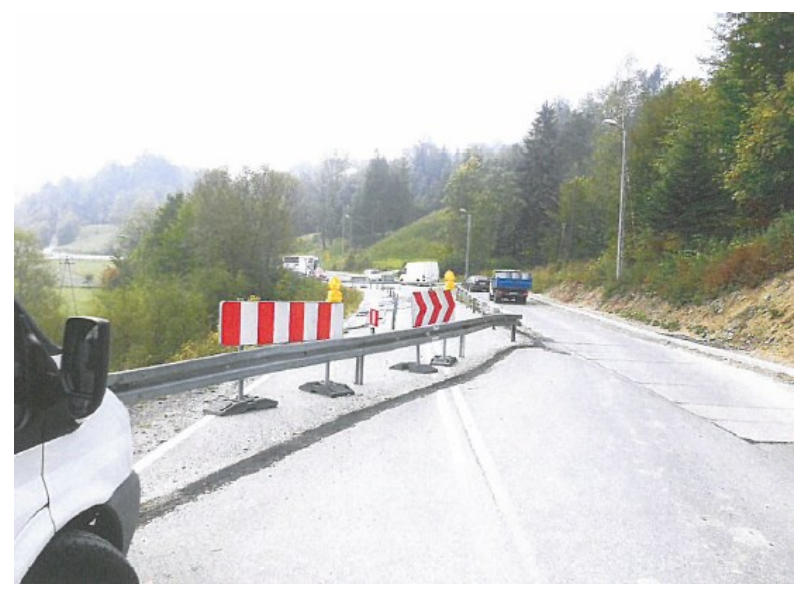

Fig.2. Road surface damage [5].

Among the causes of landslide movements in this area the following factors may be included $[5,6]$ :

- infiltration of rainwater and snowmelt,

- lateral and deep erosion of the Biała River,

- geological structure (occurrence of shales and sandstones in the ground, as well as the weathering of flysch formations, arrangement of layers, tectonic deformations),

- slope inclination conducive to landslides.

\section{Problems of the area of study}

The bridge structure located in the landslide prone area in Kąclowa, along voivodeship road No. 981, section 100 on the Grybów - Krynica Zdrój route, carries the vehicle and pedestrian traffic of the voivodeship road over an active landslide area.

Before the bridge structure was built, voivodeship road No. 981 was a single carriageway, with two lanes leading in opposite directions, along the road embankment. It passed through a vast landslide prone location with an area of over 4 hectares, which consists of 5 activity zones. Within the ground, three active zones were found, one periodically active and one inactive. The range of landslide activity zones near the bridge is shown in Figure 3.

A significant area of the road passed through the active landslide area which destroyed the road. No damage resulting from landslide movements was observed within the residential and farm buildings adjacent to the landslide. The land and rock masses within the landslide were unstable. The most serious danger to the road was the activity of a landslide below the road.

The purpose of the investment, including the extension of voivodeship road No. 981, section 100 was to restore the technical parameters of the existing road and the continuity of vehicle traffic on the section of the damaged road body. Efforts were also made to eliminate the threats resulting from landslides occurring in areas prone to active landslides. This goal was achieved by rebuilding the voivodeship road on the embankment, in the location of the active landslide zone as the bridge structure running over this zone. This investment was completed in December 2017.

A single-span bridge structure with a length of nearly $100 \mathrm{~m}$ was designed with a reinforced concrete arch structure. The bridge abutments are designed as massive reinforced 
concrete structures, set on piles embedded in layers below the landslide slip surface. Abutments were located outside the active landslide zones, just a few meters from the border of the active zone.

The slope of the cone near the abutments is $1: 1.5$. The slope at the abutment on the southeast side was reinforced with a stone pavement. Other cones were adapted to the shape of the existing terrain.

The riverbed was designed as an open construction and reinforced with stones to protect the abutment structure against wash-outing.

Construction of voivodeship road No. 981, section 100 for part of the inactive landslide was designed on a reinforced concrete grate based on reinforced concrete piles embedded below the landslide slip surface.

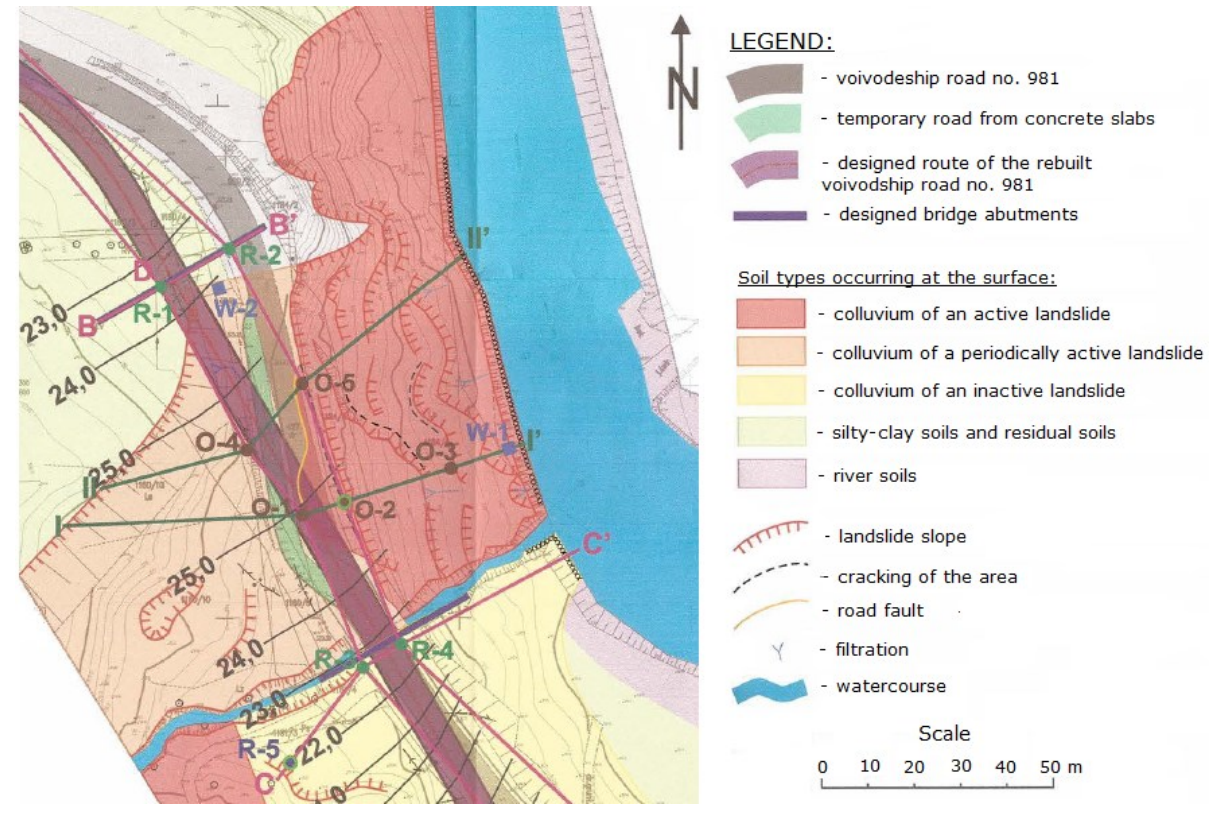

Fig. 3. Range of activity areas of the colluvium near the bridge structure [5].

\section{Displacement monitoring by terrestrial laser scanning}

The bridge structure and its immediate surroundings are monitored by constant terrestrial laser scanner monitoring. To date, two measurements have been carried out over a fourmonth period, i.e. in March 2019 and July 2019. Both measurements were made from the same measuring stations whose location was determined using GPS. The accuracy of measurement with the RIEGL VZ-400 terrestrial laser scanner is approx. $3 \mathrm{~mm}$. As stable details that permit mutual location of point clouds from two periods [10], the houses near the bridge were chosen due to the fact that they are located outside the landslide area and do not show any evidence of deformation occurred. From the overlapping of the surfaces obtained in individual measurements, a terrain differential model was created. On this basis, the size and extent of the vertical displacements of the terrain near the bridge structure were determined.

The three areas most threatened by damage to road No. 981 were adopted for analysis (Fig. 4). The areas "A" and "B" include the surroundings of the abutments at the site of the previous active landslide. Area " $\mathrm{C}$ " includes a slope located on the west side of the object, in its immediate environs. 


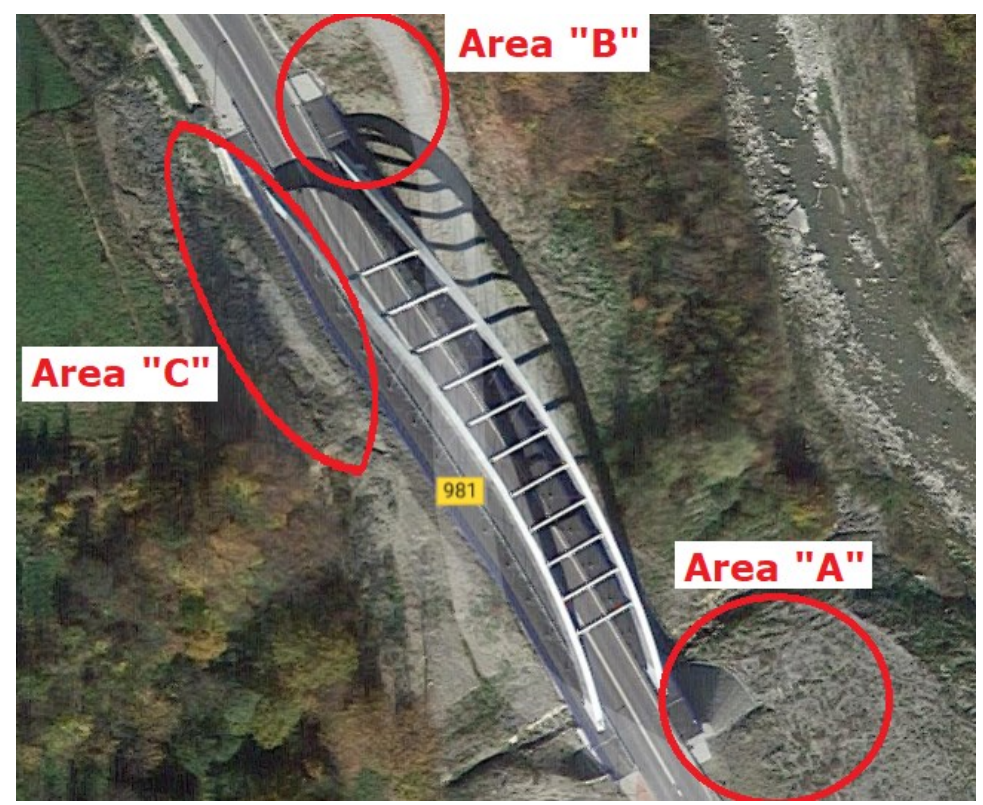

Fig. 4. Areas of research adopted for differential analysis with a terrestrial laser scanner.

The slope cone (area "A") reinforced with a stone pavement on the south-eastern side of the structure (Fig. 5) shows displacements within $+3 \mathrm{~cm}$ to $+4 \mathrm{~cm}$, similar to the embankment slope. Locally, the slope surface has displacements from $+2.5 \mathrm{~cm}$ to $-10 \mathrm{~cm}$. Deformations of the terrain surface between the road and the river are very diverse - locally there are uplifts of about $+1 \mathrm{~cm}$, as well as lowering in the area to $-8 \mathrm{~cm}$.

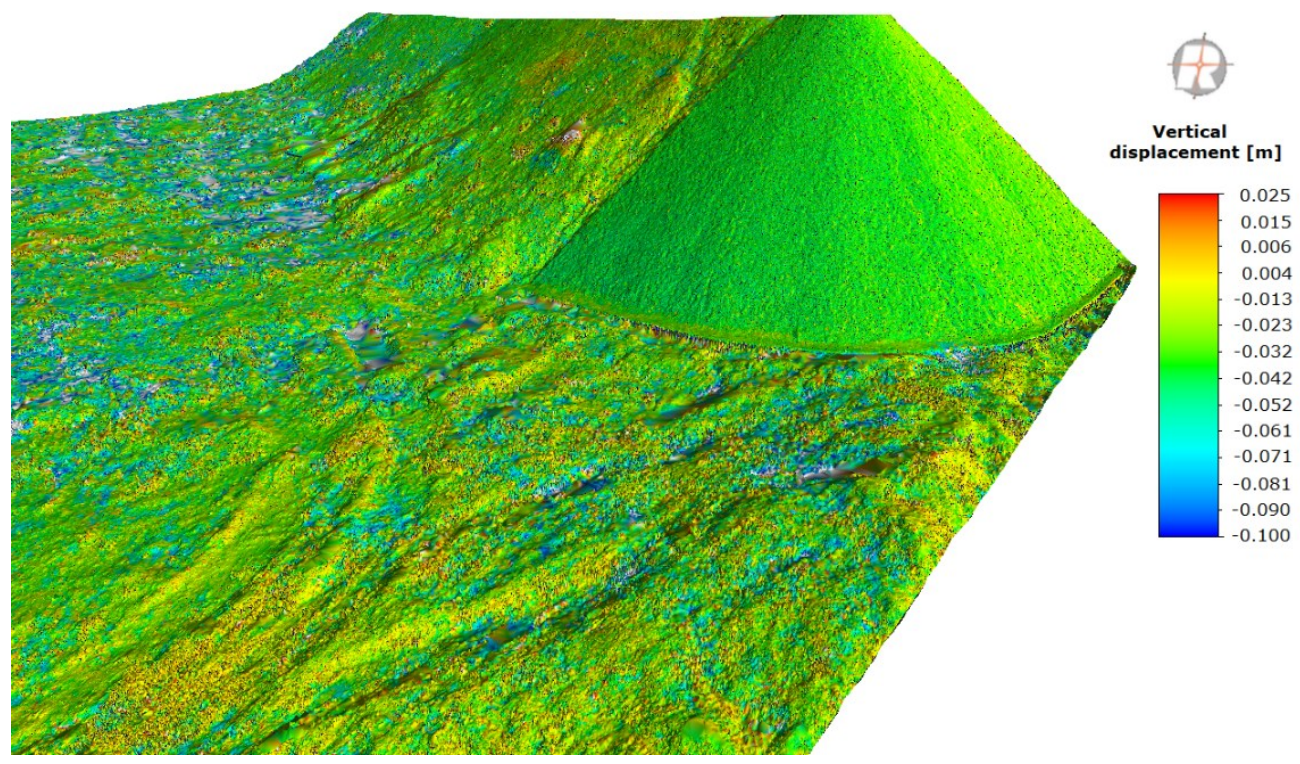

Fig. 5. Laser scanning differential model - vertical displacements of the "A" area. 


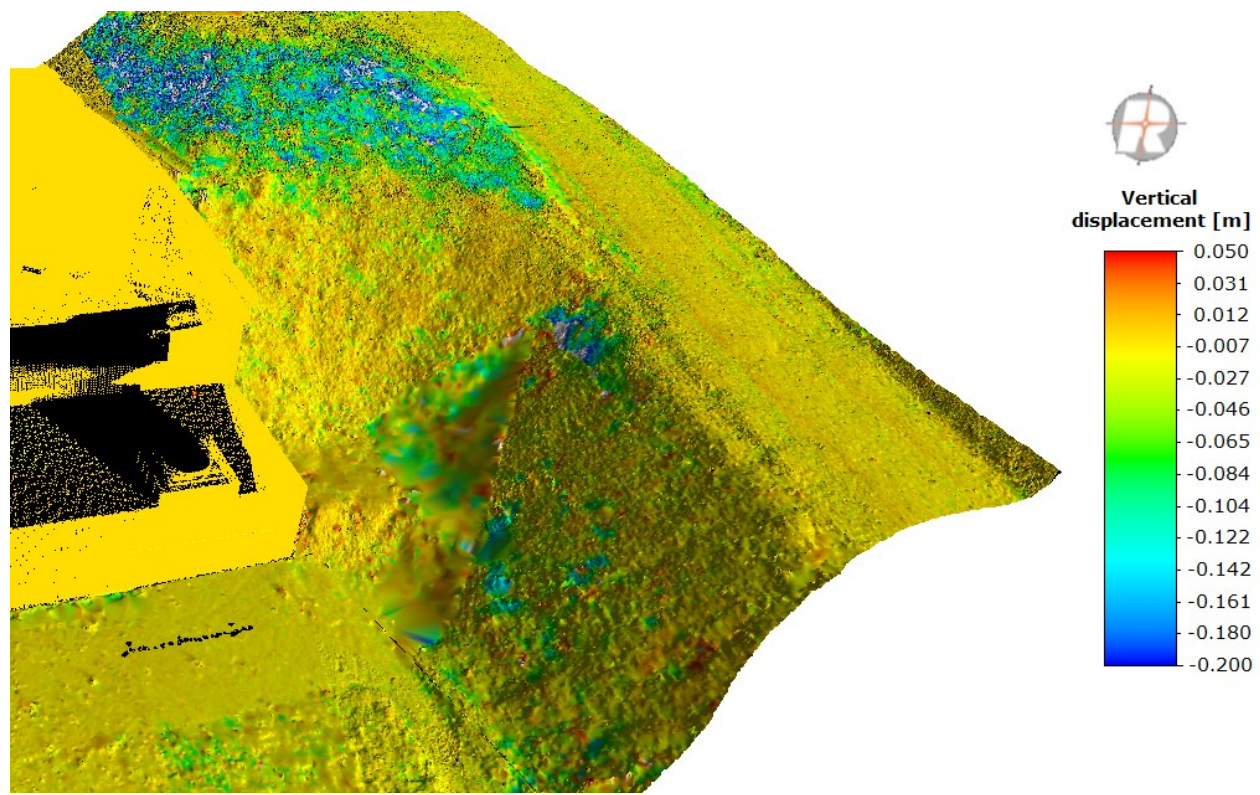

Fig. 6. Laser scanning differential model - vertical displacements of the "B" area.

The slope at the northern side (Fig. 6) is dominated by a $+1 \mathrm{~cm}$ displacement. Locally there are displacements from $-5 \mathrm{~cm}$ to $-15 \mathrm{~cm}$. The largest displacements (up to $-20 \mathrm{~cm}$ ) occur at the slope next to the road.

The slope on the west side (Fig. 7) in the lower part shows displacements of up to $+5 \mathrm{~cm}$. In the upper part of the slope, land depression of $-2 \mathrm{~cm}$ to $-5 \mathrm{~cm}$ is visible.

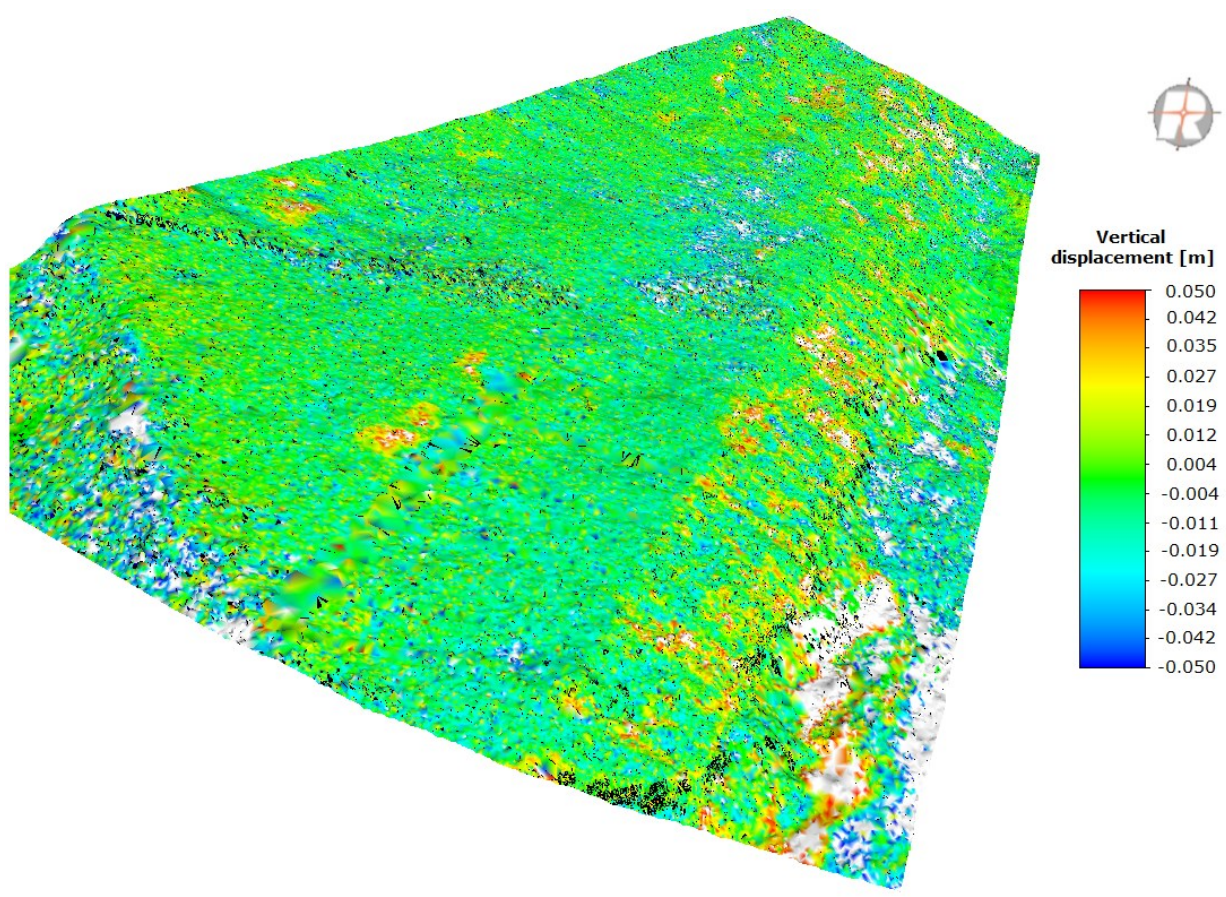

Fig. 7. Laser scanning differential model - vertical displacements of the " $\mathrm{C}$ " area. 


\section{Summary}

In the three areas "A", "B" and "C" which were most likely to result in damage to road No. 981, section 100 due to landslides in Kąclowa, tests were carried out with a terrestrial laser scanner. Monitoring with a terrestrial laser scanner allowed for the creation of a differential model. On this basis it was possible to determine the area and the size of the terrain deformation in the immediate vicinity of the bridge structure. The obtained values of displacements over a short period of time indicate landslide activity. The sizes of the displacements near the abutments range from $-8 \mathrm{~cm}$ to $-15 \mathrm{~cm}$ in places.

The cone reinforced with paving shows displacements of about $+3 \mathrm{~cm}$. The slope above the road shows evidence of landslide movement. The soil masses move down resulting in a lowering of approx. $-2 \mathrm{~cm}$ to $-5 \mathrm{~cm}$ and an uplift of approx. $+5 \mathrm{~cm}$. The values obtained from the tests conducted at a four-month interval indicate the need for the constant monitoring of the area, i.e. taking measurements at the same time interval from the same measuring stations. Due to constant monitoring, it will be possible to observe potential threats related to the increased movement of landslide masses on this section of road No. 981.

\section{References}

1. E. Pilecka, J. Kogut, D. Szwarkowski, Analysis of landslide effects along a road located in the Carpathian flysch, Open Geosci. 10(1), 517-531 (2018) doi: 10.1515/geo-20180041

2. E. Pilecka, J. Kogut, D. Szwarkowski, Monitoring and numerical modeling of a road in landslide terrain, Civil and Environmental Engineering Reports 28(2) 150-163 (2018) doi: 10.2478/ceer-2018-0026

3. www.riegl.com, access: 15.03 .2019

4. M. Jaboyedoff, T. Oppikofer, A. Abellán et al., Use of LIDAR in landslide investigations: a review, Nat. Hazards 61(1), 5-28 (2012) doi: 10.1007/s1 1069-010-9634-2

5. Projekt architektoniczno-budowlany dla zadania „Rozbudowa drogi wojewódzkiej nr 981 Zborowice-Grybów-Krzyżówka-Krynica odc. 100 od km 3+720,00 do km 4+200,00 wraz z infrastrukturą w ramach zadania pn: „Stabilizacja osuwiska wraz z odbudową

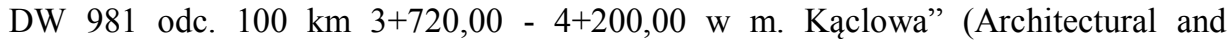
construction design for the task "Development of voivodeship road No. 981 ZborowiceGrybów-Krzyżówka-Krynica, section 100 from km $3+720.00$ to km $4+200.00$ with infrastructure as part of the task:" Landslide stabilization with the reconstruction of DW 981 section $100 \mathrm{~km} 3+720.00-4+200.00$ in the town of Kąclowa"), Łącko (2016) (in Polish)

6. Dokumentacja geologiczno-inżynierska dla stabilizacji osuwiska w ciągu DW 981 odcinek 100 km 3+890 - 3+980 w miejscowości Kąclowa, Q-5583 (Geological and engineering documentation for landslide stabilization within DW 981, $100 \mathrm{~km}$ section 3 + 890 - 3 + 980 in Kąclowa, Q-5583), Kraków (2015) (in Polish)

7. E. Pilecka, D. Szwarkowski, T. Manterys, Wpływ drgań drogowych na propagacje deformacji wzdluz czynnej powierzchni poślizgu i stateczność nasypów na terenach osuwiskowych (Influence of road vibrations on propagation deformations along the active slip surface and embankment stability in landslide areas), Autobusy 6/2016 (2016) (in Polish)

8. E. Pilecka, D. Szwarkowski, Diagnostyka nasypu drogowego zlokalizowanego na czynnym osuwisku z wykorzystaniem naziemnego skaningu laserowego i numerycznego 
modelowania (Road embankment diagnostics located on an active landslide using ground laser scanning and numerical modeling), Autobusy 12/2016 (2016) (in Polish)

9. Rozporzadzenie Ministra Transportu, Budownictwa i Gospodarki z dnia 25 kwietnia 2012 r (Dz.U 2012 poz. 463) w sprawie ustalania geotechnicznych warunków posadawiania obiektów budowlanych (Regulation of the Minister of Transport, Construction and Maritime Economy of 25 April 2012 on the establishment of the geotechnical conditions of foundation of buildings (Journal of Laws, item 463)) (in Polish)

10. M. Barbarella, M.Fiani, A. Lugi, Landslide monitoring using multitemporal terrestrial laser scanning for ground displacement analysis, Geomat. Nat. Haz. Risk. 6, 395-418 (2015) doi: 10.1080/19475705.2013.863808 